\title{
Transcutaneous Carbon Dioxide Monitoring in Subjects With Acute Respiratory Failure and Severe Hypercapnia
}

\author{
Yolanda Ruiz MD, Eva Farrero MD PhD, Ana Córdoba MD PhD, Nuria González MD, \\ Jordi Dorca MD PhD, and Enric Prats MD PhD
}

\begin{abstract}
BACKGROUND: Transcutaneous carbon dioxide $\left(\mathrm{P}_{\mathrm{tcCO}}\right)$ monitoring is being used increasingly to assess acute respiratory failure. However, there are conflicting findings concerning its reliability when evaluating patients with high levels of $\mathrm{P}_{\mathrm{aCO}}$. Our study evaluates the accuracy of this method in subjects with respiratory failure according to the severity of hypercapnia. METHODS: We included subjects with respiratory failure, admitted to a respiratory intermediate care unit, who required arterial blood gas analysis. Simultaneously, $\mathbf{P}_{\mathrm{tcCO}}$ was measured using a digital monitor. Relations between $\mathrm{P}_{\mathrm{aCO}}$ and $\mathrm{P}_{\mathrm{tcCO}}$ were assessed by the Pearson correlation coefficient. BlandAltman analysis was used to test data dispersion, and an analysis of variance test was used to compare the differences between $\mathbf{P}_{\mathrm{aCO}}$ and the corresponding $\mathbf{P}_{\mathrm{tcCO}}$ at different levels (level 1 , $<50 \mathrm{~mm} \mathrm{Hg}$; level 2, 50-60 mm Hg; level 3, >60 mm Hg). RESULTS: Eighty-one subjects were analyzed. The main diagnosis was COPD exacerbation (45\%). $\mathrm{P}_{\mathrm{tcCO}_{2}}$ correlated well with $\mathrm{P}_{\mathrm{aCO}}$ $(\mathrm{r} 2=0.93, P<.001)$. Bland-Altman analysis showed a mean $\mathrm{P}_{\mathrm{aCO}_{2}}-\mathrm{P}_{\mathrm{tcCO}_{2}}$ difference of $4.9 \pm 4.4$ with $95 \%$ limits of agreement ranging from -3.6 to 13.4. The difference between variables increased in line with $P_{\mathrm{aCO}}$, severity: level $1,1.7 \pm 3.2 \mathrm{~mm} \mathrm{Hg}$; level 2, $3.7 \pm 2.8$; level 3, $6.8 \pm 4.7$ (analysis of variance, $P<$.001). CONCLUSIONS: Our study showed an acceptable agreement of $\mathbf{P}_{\text {tcCO }}$ monitoring with arterial blood gas analysis. However, we should consider that $\mathbf{P}_{\text {tccO }}$ underestimates $\mathbf{P}_{\mathrm{aCO}}$ levels, and its accuracy depends on the level of hypercapnia, so this method would not be suitable for acute patients with severe hypercapnia. Key words: hypercapnia; noninvasive ventilation; respiratory care units; respiratory insufficiency; transcutaneous blood gas monitoring; transcutaneous carbon dioxide partial pressure determination; transcutaneous capnometry. [Respir Care 2016;61(4):428-433. (C) 2016 Daedalus Enterprises]
\end{abstract}

\section{Introduction}

Transcutaneous carbon dioxide $\left(\mathrm{P}_{\mathrm{tcCO}_{2}}\right)$ monitoring is an increasingly popular noninvasive method for assessing

\footnotetext{
The authors are affiliated with the Respiratory Department, Hospital Universitario de Bellvitge, Hospitalet de Llobregat, Barcelona, Spain.

Dr Prats presented a version of this paper at the European Respiratory Society 2014 annual meting, held September 6-10, 2014, in Munich, Germany.

The authors have disclosed no conflicts of interest.

Correspondence: Yolanda Ruiz MD, Feixa Llarga s/n, 08907 Hospitalet de Llobregat, Spain. E-mail: yolanda.ruiz@bellvitgehospital.cat.
}

DOI: $10.4187 /$ respcare. 04283 alveolar ventilation. This procedure has the advantage over arterial blood samples of avoiding pain and providing continuous monitoring.

Several studies have reported a good agreement between $\mathrm{P}_{\mathrm{tcCO}}$ and $\mathrm{P}_{\mathrm{aCO}}$ in different subject populations, such as: pediatric critical care, ${ }^{1}$ sleep laboratories, ${ }^{2}$ out-patients, ${ }^{3}$ during major surgery, ${ }^{4}$ in emergency departments, ${ }^{5}$ and ICUs. ${ }^{6}$

The accuracy of $\mathrm{P}_{\text {tcCO}}$ has also been studied in acute respiratory failure settings with a variety of results, which range from a very good agreement to unacceptable results for clinical practice. ${ }^{6-12}$ This controversy could be explained by the heterogeneity of diagnosis and by the fact that the number of subjects with severe ventilatory abnormalities is very different in these studies.

However, when we look at the studies that have evaluated subjects with high levels of $\mathrm{P}_{\mathrm{aCO}_{2}}$, conflicting find- 


\section{$\mathrm{P}_{\mathrm{tcCO}_{2}}$ Monitoring in Acute Respiratory Failure and Severe Hypercapnia}

ings are continuously observed. Some authors suggest that at high $\mathrm{P}_{\mathrm{aCO}}$ values, larger differences between $\mathrm{P}_{\mathrm{tcCO}}$ and $\mathrm{P}_{\mathrm{aCO}_{2}}$ are observed.9,13 In contrast, other studies ${ }^{6-8}$ consider that the agreement between the 2 methods is independent of the level of $\mathrm{P}_{\mathrm{aCO}}$. These differences are especially relevant in situations of acute respiratory failure, when the level of hypercapnia may condition therapeutic decisions, such as the need for mechanical ventilation. The aim of our study was to assess the accuracy of $\mathrm{P}_{\mathrm{tcCO}}$ in subjects with acute respiratory failure according to the severity of hypercapnia.

\section{Methods}

\section{Study Design}

This was a prospective observational study. Written informed consent was not considered necessary for the study, given its non-interventional nature. The data of the subjects were anonymized for the purposes of analysis. Confidential information regarding subjects was protected according to Spanish regulations. The study was approved by the Clinical Research Ethics Committee of Bellvitge University Hospital.

\section{Study Setting and Population}

The study was conducted in a respiratory intermediate care unit at the Bellvitge University Hospital, a teaching hospital with 600 beds, between June 2012 and December 2013. The annual new patient attendance at this respiratory intermediate care unit is approximately 250 . Patients with respiratory failure (acute or acute-on-chronic) who required arterial blood gas analysis as a part of their care were eligible for inclusion.

\section{Study Protocol, Measurements, and Data Collection}

Eligible subjects were identified and enrolled by one of the senior respiratory intermediate care unit physicians trained in the use of the $\mathrm{P}_{\mathrm{tcCO}_{2}}$ monitor. $\mathrm{P}_{\mathrm{tcCO}}$ was measured using a digital monitor (SenTec, Therwill, Switzerland). After automatic calibration, carried out according to the manufacturer's recommendations, a probe was placed on the subject's upper chest using a drop of conductive solution. The sensor was heated to $42^{\circ} \mathrm{C}$ over $5 \mathrm{~min}$, inducing local vasodilatation to increase skin permeability to $\mathrm{CO}_{2}$. A minimum of $20 \mathrm{~min}$ was allowed for stabilization, and an arterial blood gas sample was obtained from the radial artery. The $\mathrm{P}_{\mathrm{tcCO}}$ reading on the monitor at the moment of the withdrawal of the needle was recorded. Arterial blood gases were analyzed immediately using an ABL800 FLEX gas analyzer (Radiometer, Copenhagen, Denmark) and expressed in $\mathrm{mm} \mathrm{Hg}$.

\section{QUICK LOOK}

\section{Current knowledge}

Transcutaneous carbon dioxide $\left(\mathrm{P}_{\mathrm{tcCO}_{2}}\right)$ monitoring is an increasingly popular noninvasive method for assessing acute respiratory failure. This procedure has the advantage over arterial blood samples of avoiding pain and providing continuous monitoring. However, there are conflicting findings concerning its reliability when evaluating patients with high levels of $\mathrm{P}_{\mathrm{aCO}}$.

\section{What this paper contributes to our knowledge}

In subjects with acute respiratory failure, a portable $\mathrm{P}_{\mathrm{tcCO}_{2}}$ device provided an acceptable assessment of $\mathrm{P}_{\mathrm{aCO}_{2}}$ when compared with the accepted standard measurement of $\mathrm{P}_{\mathrm{aCO}}$. However, $\mathrm{P}_{\mathrm{tcCO}}$ underestimated $\mathrm{P}_{\mathrm{aCO}}$ levels, and its accuracy depended on the level of hypercapnia. $\mathrm{P}_{\mathrm{tcCO}_{2}}$ was less reliable in subjects with severe hypercapnia.

The data collected included subject demographics, body mass index, cause of respiratory failure, vital signs, use of vasoactive drugs, oxygen $\left(\mathrm{F}_{\mathrm{IO}_{2}}\right)$ or use of noninvasive ventilation, arterial blood gas analysis, and $\mathrm{P}_{\mathrm{tcCO}_{2}}$ measurements.

\section{Data Analysis}

Descriptive data are presented as mean $\pm \mathrm{SD}$ and as $n$ (\%). The Pearson correlation coefficient was used to evaluate the linear relationship between the paired arterial and transcutaneous carbon dioxide measurements. Agreement between these 2 variables was estimated using the BlandAltman method. Bias (the mean difference between $\mathrm{P}_{\mathrm{aCO}}$ and $\mathrm{P}_{\mathrm{tcCO}_{2}}$ ) and $95 \%$ limits of agreement were calculated. With the purpose of analyzing the behavior of the $\mathrm{P}_{\mathrm{tcCO}_{2}}$ in relation to hypercapnia, an analysis of variance test was performed to compare the bias between paired $\mathrm{P}_{\mathrm{aCO}_{2}}-\mathrm{P}_{\mathrm{tcCO}}$ measurements at different levels of $\mathrm{P}_{\mathrm{aCO}}$ (level 1, $<50 \mathrm{~mm} \mathrm{Hg}$; level 2, 50-60 mm Hg; level 3, $>60 \mathrm{~mm} \mathrm{Hg}$ ). Values of $P<.05$ were considered statistically significant. Statistical tests were run using SPSS 16 for Windows (SPSS, Chicago, Illinois).

\section{Results}

Ninety-five subjects were enrolled in the study. Eleven measurements were excluded because venous blood gases were drawn, and technical problems with the monitor led to the exclusion of 3 subjects. A total of 81 subjects were 


\section{$\mathrm{P}_{\mathrm{tcCO}_{2}}$ Monitoring in Acute Respiratory Failure and Severe Hypercapnia}

Table 1. Characteristics of Study Subjects $(\mathrm{N}=81)$

\begin{tabular}{|c|c|}
\hline Characteristics & Values \\
\hline Age, mean $\pm \mathrm{SD}$ y & $66 \pm 11$ \\
\hline Male sex, $n(\%)$ & $49(60.5 \%)$ \\
\hline $\mathrm{BMI}$, mean $\pm \mathrm{SD} \mathrm{kg} / \mathrm{m}^{2}$ & $34 \pm 9$ \\
\hline Systolic arterial blood pressure, mean $\pm \mathrm{SD} \mathrm{mm} \mathrm{Hg}$ & $127 \pm 16$ \\
\hline Diastolic arterial blood pressure, mean $\pm \mathrm{SD} \mathrm{mm} \mathrm{Hg}$ & $69 \pm 12$ \\
\hline \multicolumn{2}{|l|}{ Diagnosis at admission, $n(\%)$} \\
\hline COPD exacerbation & $34(45)$ \\
\hline Chest wall diseases & $12(16)$ \\
\hline Neuromuscular disease & $5(7)$ \\
\hline Obesity hypoventilation syndrome & $22(29)$ \\
\hline Asthma & $1(1)$ \\
\hline Pneumonia & $2(3)$ \\
\hline Noninvasive ventilation, $n(\%)$ & $31(38)$ \\
\hline Vasoactive drugs, $n(\%)$ & $2(2.5)$ \\
\hline Oxygen supplementation, $n(\%)$ & $58(72)$ \\
\hline \multicolumn{2}{|l|}{ Blood gases, mean $\pm \mathrm{SD}$} \\
\hline $\mathrm{pH}$ & $7.30 \pm 0.8$ \\
\hline $\mathrm{P}_{\mathrm{aO}_{2}}, \mathrm{~mm} \mathrm{Hg}$ & $70.1 \pm 17.3$ \\
\hline $\mathrm{P}_{\mathrm{aCO}}, \mathrm{mm} \mathrm{Hg}$ & $59.8 \pm 11.9$ \\
\hline 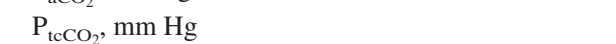 & $54.9 \pm 10.4$ \\
\hline
\end{tabular}

BMI = body mass index

Table 2. Agreement Between $\mathrm{P}_{\mathrm{aCO}_{2}}$ and $\mathrm{P}_{\mathrm{tcCO}_{2}}$ at Different Levels of $\mathrm{P}_{\mathrm{aCO}_{2}}$

\begin{tabular}{lccc}
\hline \hline & Bias $\pm \mathrm{SD}$ & $95 \% \mathrm{CI}$ & Limits of Agreement \\
\hline Level 1 $(n=13) *$ & $1.77 \pm 3.29$ & -0.22 to 3.76 & -4.6 to 8.22 \\
Level 2 $(n=29) \dagger$ & $3.69 \pm 2.84$ & $2.61-4.77$ & -1.8 to 9.23 \\
Level 3 $(n=39) \dagger$ & $6.77 \pm 4.75$ & $5.22-8.31$ & -2.5 to 16.11 \\
& & & \\
$* \mathrm{P}_{\mathrm{aCO}}<50 \mathrm{~mm} \mathrm{Hg}$. & & \\
$\dagger \mathrm{PaCO}_{2}=50-60 \mathrm{~mm} \mathrm{Hg}$. & & \\
$\ddagger \mathrm{P}_{\mathrm{aCO}}>60 \mathrm{~mm} \mathrm{Hg}$. & & \\
\hline
\end{tabular}

analyzed with paired measurements for arterial and transcutaneous carbon dioxide tension recorded for each one.

The clinical characteristics of the subjects included are presented in Table 1 . The mean age was $66 \pm 11 \mathrm{y}$. COPD exacerbation (34 subjects or $45 \%$ ) was the main final diagnosis, followed by obesity hypoventilation syndrome (22 subjects or $22 \%$ ). At the time of arterial blood sampling, $72 \%$ of the subjects were receiving oxygen, and $38 \%$ were receiving noninvasive ventilation. None of the subjects studied were in shock or hypothermic, and only 2 required inotropic support. Mean $\mathrm{P}_{\mathrm{aCO}_{2}}$ was $59.8 \pm 11.9 \mathrm{~mm} \mathrm{Hg}$ (range 30-99 $\mathrm{mm} \mathrm{Hg}$ ), and mean $\mathrm{P}_{\mathrm{tcCO}}$ was $54.9 \pm 10.4 \mathrm{~mm} \mathrm{Hg}$ (range $29-80 \mathrm{~mm} \mathrm{Hg}$ ). In relation to $\mathrm{P}_{\mathrm{aCO}_{2}}$ level, subjects were distributed as follows: level $1(<50 \mathrm{~mm} \mathrm{Hg}), 13(16 \%)$; level $2(50-$ $60 \mathrm{~mm} \mathrm{Hg}$ ), 29 (36\%); level 3 (>60 mm Hg), 39 (48\%). The differences between paired $\mathrm{P}_{\mathrm{aCO}}-\mathrm{P}_{\mathrm{tcCO}_{2}}$ measurements at different levels of $\mathrm{P}_{\mathrm{CO}_{2}}$ are provided in Table 2.

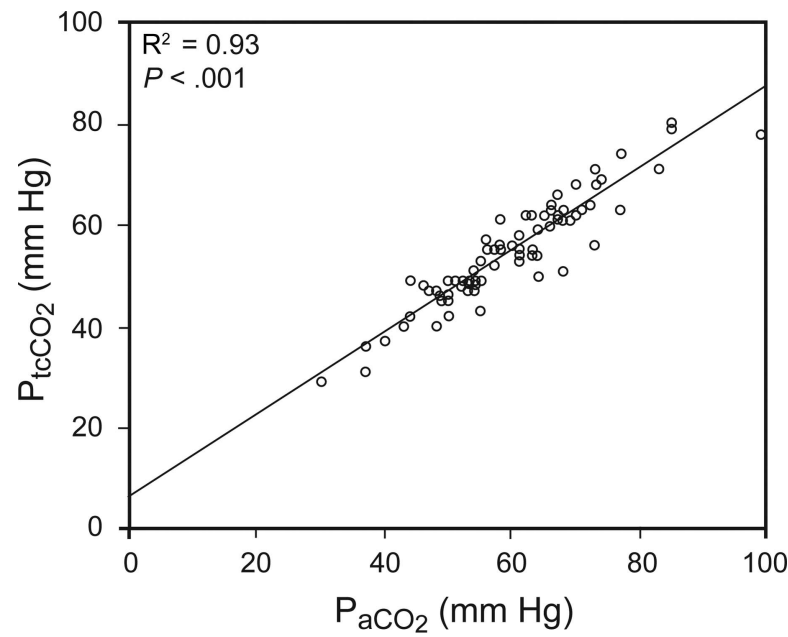

Fig. 1. Linear correlation between transcutaneous $\mathrm{CO}_{2}\left(\mathrm{P}_{\mathrm{tcCO}_{2}}\right)$ and arterial $\mathrm{CO}_{2}\left(\mathrm{P}_{\mathrm{aCO}_{2}}\right)$.

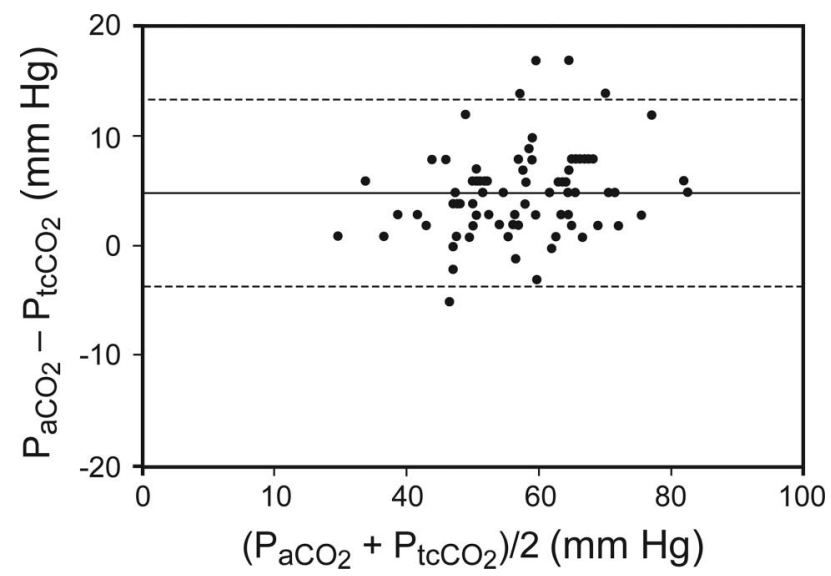

Fig. 2. Bland-Altman analysis between paired measurements of arterial $\mathrm{P}_{\mathrm{CO}_{2}}\left(\mathrm{P}_{\mathrm{aCO}}\right)$ and transcutaneous $\mathrm{CO}_{2}\left(\mathrm{P}_{\mathrm{tcCO}_{2}}\right)$. The solid line represents the mean difference between the 2 methods, and the dotted lines denote the limits of agreement ( $\pm 1.96 \mathrm{SD}$ ).

There was a high correlation between $\mathrm{P}_{\mathrm{aCO}}$ and $\mathrm{P}_{\mathrm{tcCO}}$, as shown in Figure $1 ; \mathrm{R}^{2}$ was $0.93(P<.001)$. The Bland-Altman plot of all the subjects included in the study is presented in Figure 2. The mean bias between the 2 methods of measurement was 4.9 , and limits of agreement (bias $\pm 1.96 \mathrm{SD}$ ) ranged from -3.6 to 13.4. We also calculated the bias and the limits of agreement between the parameters for each group separately (Fig. 3 ). In the group of more severe hypercapnic subjects with $\mathrm{P}_{\mathrm{aCO}_{2}}>60 \mathrm{~mm} \mathrm{Hg}$, the Bland-Altman test showed a mean bias of 6.7 and limits of agreement from -2.5 to 16.1 .

We performed an analysis of variance (Fig. 4) to analyze the effect of the different levels of $\mathrm{P}_{\mathrm{aCO}_{2}}$ on the bias from the blood samples and the corresponding $\mathrm{P}_{\mathrm{tcCO}}$. The difference between both variables increases in line with 

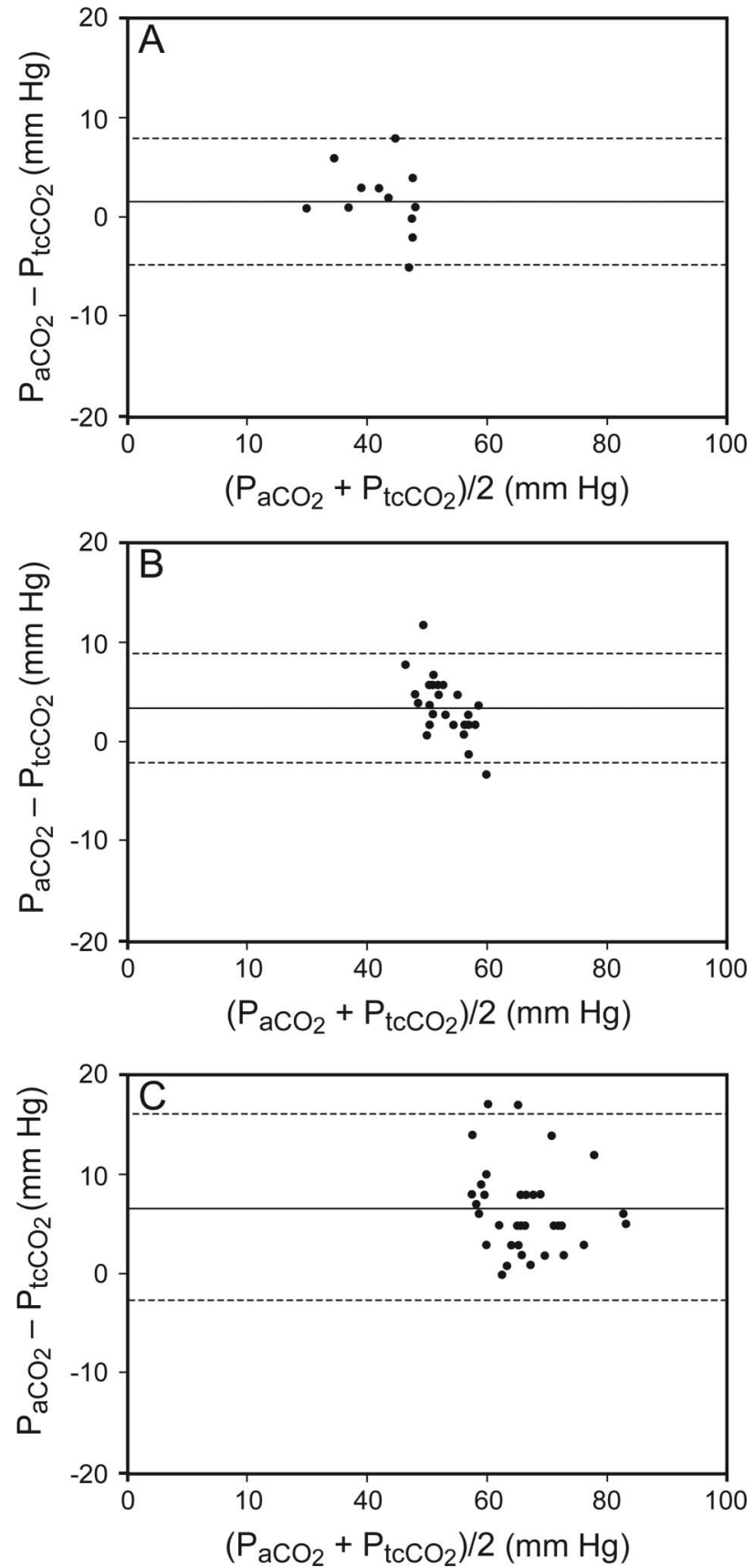

Fig. 3. Bland-Altman analysis between paired measurements of arterial $\mathrm{P}_{\mathrm{CO}_{2}}\left(\mathrm{P}_{\mathrm{aCO}}\right)$ and transcutaneous $\mathrm{CO}_{2}\left(\mathrm{P}_{\mathrm{tcCO}}\right)$ for each group of subjects: level $1 \mathrm{P}_{\mathrm{aCO}_{2}}<50 \mathrm{~mm} \mathrm{Hg}(\mathrm{A})$; level $2 \mathrm{P}_{\mathrm{acO}_{2}} 50-60 \mathrm{~mm}$ $\mathrm{Hg}(\mathrm{B})$; level $3 \mathrm{P}_{\mathrm{aCO}_{2}}>60 \mathrm{~mm} \mathrm{Hg}(\mathrm{C})$. Solid lines represent the mean difference between the 2 methods, and the dashed lines denote the limits of agreement ( $\pm 1.96 \mathrm{SD})$.

$\mathrm{P}_{\mathrm{aCO}_{2}}$ severity: level 1, $1.77 \pm 3.29 \mathrm{~mm} \mathrm{Hg}$; level 2, $3.69 \pm 2.84$; level 3, $6.77 \pm 4.75$ (analysis of variance, $P<.001$ ). During this study, we did not observe any adverse effects from or subject discomfort with the heating electrode, and no skin lesions were found after probe removal.

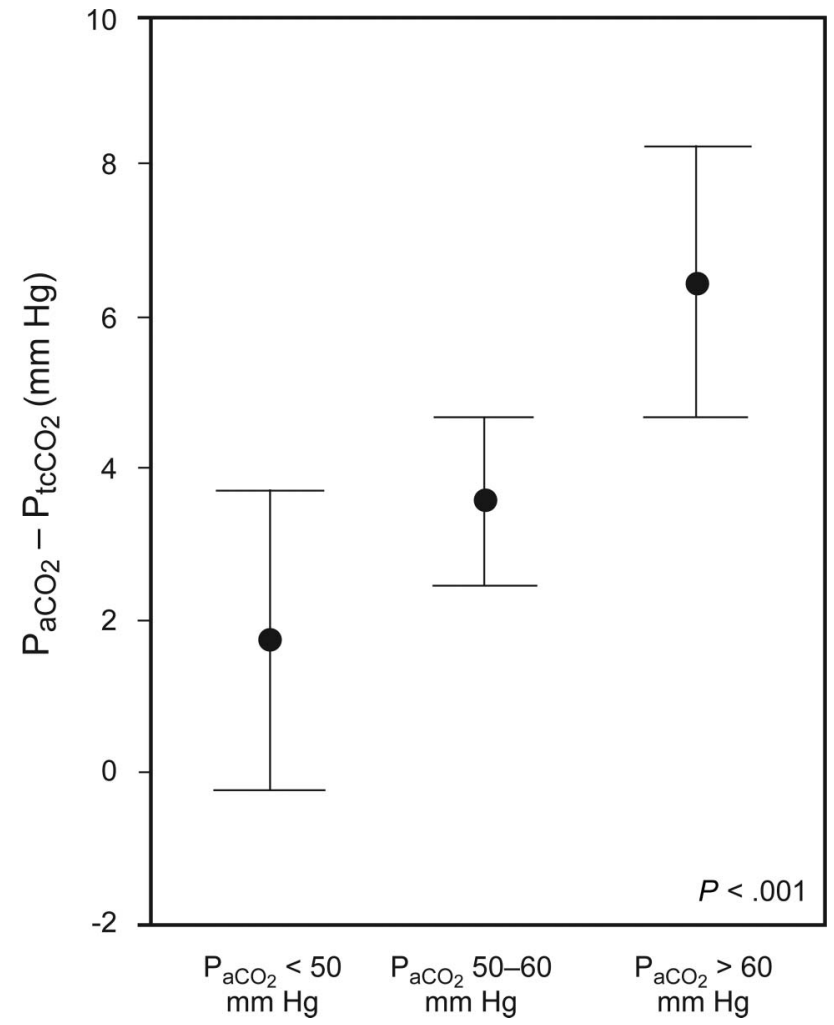

Fig. 4. Analysis of variance test to analyze the bias related to $\mathrm{P}_{\mathrm{aCO}}-\mathrm{P}_{\mathrm{tcCO}_{2}}$ couple at different levels of $\mathrm{P}_{\mathrm{aCO}_{2}}$.

\section{Discussion}

The present study evaluated the accuracy of the SenTec digital monitor for $\mathrm{P}_{\mathrm{tcCO}}$ measurements in subjects with acute respiratory failure according to the severity of hypercapnia. Although we generally found good agreement between transcutaneous carbon dioxide and $\mathrm{P}_{\mathrm{aCO}_{2}}$, the measurements of $\mathrm{P}_{\mathrm{tcCO}_{2}}$ were less reliable in subjects with severe hypercapnia. In fact, in the group of subjects with higher $\mathrm{P}_{\mathrm{aCO}}$ values, the bias between $\mathrm{P}_{\mathrm{tcCO}}$ and $\mathrm{P}_{\mathrm{aCO}}$ was clinically relevant and could interfere with the interpretation of the results and the management of the respiratory failure.

Although several studies that have investigated the accuracy of $\mathrm{P}_{\mathrm{tcCO}_{2}}$ monitoring in subjects with acute respiratory failure have found a good agreement between the 2 methods, most of them did not evaluate patients with high hypercapnia levels. For instance, in subjects admitted to an emergency department, Delerme et $\mathrm{al}^{5}$ found that the mean difference between $\mathrm{P}_{\mathrm{aCO}}$ and $\mathrm{P}_{\mathrm{tcCO}}$ was $1 \mathrm{~mm} \mathrm{Hg}$ with limits of agreement of -3.4 to 5.6 and that all $\mathrm{P}_{\mathrm{tcCO}_{2}}$ values were within $5 \mathrm{~mm} \mathrm{Hg}$ of $\mathrm{P}_{\mathrm{aCO}_{2}}$ values. In subjects with severe asthma or pneumonia, Perrin et al ${ }^{11}$ obtained a bias of $-0.13 \mathrm{~mm} \mathrm{Hg}$ with limits of agreement of -3.9 and $3.7 \mathrm{~mm} \mathrm{Hg}$. McVicar and Eager ${ }^{12}$ found a mean difference of $0.15 \mathrm{~mm} \mathrm{Hg}$, and the limits of agreement were -6 


\section{$\mathrm{P}_{\mathrm{tcCO}_{2}}$ Monitoring in Acute Respiratory Failure and Severe Hypercapnia}

to $6.2 \mathrm{~mm} \mathrm{Hg}$. It should be noted that mean $\mathrm{P}_{\mathrm{aCO}_{2}}$ in these 3 studies was $<50 \mathrm{~mm} \mathrm{Hg}$ (39, 36, and $41 \mathrm{~mm} \mathrm{Hg}$ respectively). Conversely, ours was $59 \mathrm{~mm} \mathrm{Hg}$, and $48 \%$ of the cases were in the group of $\mathrm{P}_{\mathrm{aCO}_{2}}>60 \mathrm{~mm} \mathrm{Hg}$. This could explain why, in a similar setting of acute respiratory failure, our bias and limits of agreement are worse than those reported previously.

To our knowledge, this is the first study that has purposely assessed the validity of transcutaneous measurements in subjects with different levels of hypercapnia, including a high number of severe hypercapnic patients. According to our results, the difference between the 2 variables increases as the level of $\mathrm{P}_{\mathrm{aCO}}$ rises. The group with $\mathrm{P}_{\mathrm{aCO}_{2}}>60 \mathrm{~mm} \mathrm{Hg}$ showed a bias of 6.7 , with limits of agreement of -2.5 and 16 . Our findings are consistent with those of other authors, ${ }^{13,14}$ who have argued that the reliability and accuracy of this method decreases when evaluating severe ventilatory disturbance with high levels of $\mathrm{P}_{\mathrm{aCO}_{2}}$. Storre et al, ${ }^{13}$ who used a SenTec digital monitor, reported a bias of $4.6 \mathrm{~mm} \mathrm{Hg}$ and limits of agreement of -3.9 and $13.2 \mathrm{~mm} \mathrm{Hg}$ in 10 subjects with a mean $\mathrm{P}_{\mathrm{aCO}_{2}}$ of $67 \mathrm{~mm} \mathrm{Hg}$. Kelly and Klim, ${ }^{9}$ using a Radiometer TCM4 device in subjects undergoing noninvasive ventilation, found a poor agreement between $\mathrm{P}_{\mathrm{aCO}}$ and $\mathrm{P}_{\mathrm{tcCO}}$. In this study, mean $\mathrm{P}_{\mathrm{aCO}_{2}}$ was $60 \mathrm{~mm} \mathrm{Hg}$, and the bias was 6.1, with limits of agreement of -10 and $22 \mathrm{~mm} \mathrm{Hg}$.

In contrast, in a study designed to assess the accuracy of a TOSCA monitor in ICU subjects with varying $\mathrm{P}_{\mathrm{aCO}_{2}}$, Bendjelid et $\mathrm{al}^{6}$ concluded that the agreement between the 2 methods was independent of the level of $\mathrm{P}_{\mathrm{aCO}_{2}}$. However, the study did not discriminate high $\mathrm{P}_{\mathrm{aCO}_{2}}$ values because the hypercapnic group was defined by $\mathrm{P}_{\mathrm{aCO}_{2}}>$ $42 \mathrm{~mm} \mathrm{Hg}$. In addition, the authors did not mention the average level of $\mathrm{P}_{\mathrm{aCO}_{2}}$, but when their graphs are analyzed, it seems that most samples had a value of $<60 \mathrm{~mm} \mathrm{Hg}$. Cox et al, ${ }^{7}$ using the same monitor as Bendjelid et al ${ }^{6}$ in subjects with exacerbation of COPD, also obtained a good correlation between $\mathrm{P}_{\mathrm{aCO}}$ and $\mathrm{P}_{\mathrm{tcCO}_{2}}$. However, despite finding a small bias (mean $\mathrm{P}_{\mathrm{tcCO}_{2}}-\mathrm{P}_{\mathrm{aCO}_{2}}$ difference of $-1.1 \mathrm{~mm} \mathrm{Hg}$ ), the limits of agreement were relevant ( +4.5 to $-6.8 \mathrm{~mm} \mathrm{Hg}$ ).

In accordance with other authors, $9,14,15$ another important fact that we found was that $\mathrm{P}_{t c \mathrm{tCO}_{2}}$ values underestimate $\mathrm{P}_{\mathrm{aCO}_{2}}$ values. We observed that not only does $\mathrm{P}_{\text {tcCO}}$ underestimate $\mathrm{P}_{\mathrm{aCO}_{2}}$, but also, this underestimation becomes more pronounced as hypercapnia increases. These results are very important in clinical practice because they can give a false impression of normality, especially in patients who may require ventilatory support. Our study was carried out in a respiratory intermediate care unit, where patients with severe ventilatory failure/disturbance and severe hypercapnia predominate (COPD exacerbation, neuromuscular diseases, obesity hypoventilation syndrome). In this context, although $\mathrm{P}_{\mathrm{tcCO}_{2}}$ is useful to avoid repeated arterial blood samplings, $\mathrm{P}_{\mathrm{tcCO}}$ values need to be interpreted with caution, especially in cases with high levels of hypercapnia, and arterial blood gas analysis therefore remains the accepted standard in the management of these patients. In critically ill subjects as Rodriguez et al ${ }^{16}$ suggest, transcutaneous arterial carbon dioxide is probably more useful as a trend-monitoring tool to predict changes in $\mathrm{P}_{\mathrm{aCO}_{2}}$ than as a single measurement. In the same way, van Oppen et al ${ }^{17}$ in a pilot study demonstrate that $\mathrm{P}_{\mathrm{tcCO}_{2}}$ provides a continuous and reliable tool and also allows $\mathrm{pH}$ prediction.

Some monitor and patient factors have been described that may affect transcutaneous carbon dioxide measurements and therefore could alter the results of our study. In order to avoid technical problems like trapped air bubbles, improper placement, or inappropriate calibration, the monitor was only used by trained personnel. Body mass index, tissue hypoperfusion, and the use of vasoconstricting drugs may affect accuracy. ${ }^{18,19,20}$ In line with the results of Maniscalco et al, ${ }^{21}$ which found a good agreement between $\mathrm{P}_{\mathrm{aCO}_{2}}$ and $\mathrm{P}_{\mathrm{tcCO}_{2}}$ (bias $1.3 \mathrm{~mm} \mathrm{Hg}$ and limits of agreement -4 to 1.1 ) in a study of severe obese subjects (body mass index $43.7 \mathrm{~kg} / \mathrm{m}^{2}$ ), we considered that the body mass index of our subjects (mean $34 \mathrm{~kg} / \mathrm{m}^{2}$ ) did not affect the accuracy of $\mathrm{P}_{\text {tcCO}}$. On the other hand, only 2 hypotensive subjects were included.

This study has some limitations that should be considered. $\mathrm{P}_{\mathrm{tcCO}}$ measurements were recorded in real time, and the values were not retrospectively analyzed with the software provided by the SenTec digital monitor to correct hypothetical drift. In any case, the drift of the transcutaneous electrode would be relevant if monitoring is performed over a period of several hours ${ }^{22,23}$ and not during short-term studies like ours, so we considered that this would not alter our results. The classification of $\mathrm{P}_{\mathrm{aCO}}$ values in 3 different groups was done arbitrarily. Therefore, we are unable to establish a cut-off point corresponding to a $\mathrm{P}_{\mathrm{aCO}_{2}}$ level at which the difference is clinically unacceptable. Our study was not designed to assess the accuracy of the monitor when used to follow trends in $\mathrm{P}_{\mathrm{aCO}_{2}}$ over time because only one comparison was made. However, other authors ${ }^{16,17}$ consider $\mathrm{P}_{\text {tcCO}}$ monitoring a useful tool in the treatment of acutely ill subjects. In these cases, measurements of $\mathrm{P}_{\mathrm{tcCO}_{2}}$ would complement the arterial samples for following and monitoring trends.

Although we have evaluated a single-monitor device and consider that the level of agreement is related to the severity of hypercapnia and not to the accuracy of the SenTec digital monitor itself, further studies with different monitors and different levels of hypercapnia are probably needed to confirm our results. 


\section{$\mathrm{P}_{\mathrm{tcCO}_{2}}$ Monitoring in Acute Respiratory Failure and Severe Hypercapnia}

\section{Conclusions}

Our study suggests that in subjects with acute respiratory failure, a portable $\mathrm{P}_{\mathrm{tcCO}}$ device provides an acceptable assessment of $\mathrm{P}_{\mathrm{aCO}_{2}}$ when compared with the accepted standard measurement of $\mathrm{P}_{\mathrm{aCO}_{2}}$. However, these findings show that we have to take into account 2 clinically important aspects: $\mathrm{P}_{\mathrm{tcCO}}$ undervalues $\mathrm{P}_{\mathrm{aCO}}$ levels, and $\mathrm{P}_{\mathrm{tcCO}}$ is less reliable in patients with severe hypercapnia. Bearing in mind these limitations, we cannot recommend the use of $\mathrm{P}_{\mathrm{tcCO}_{2}}$ monitoring as a substitute for arterial blood gas analysis, especially in severely hypercapnic patients who could potentially require ventilatory support.

\section{ACKNOWLEDGMENTS}

We acknowledge the contribution of Dr Planas, Elena Garcia, and the rest of the nursing staff of the Respiratory Department (Hospital Universitario de Bellvitge) to data collection for this project.

\section{REFERENCES}

1. Bernet-Buettiker V, Ugarte MJ, Frey B, Hug MI, Baenziger O, Weiss $M$. Evaluation of a new combined transcutaneous measurement of $\mathrm{PCO}_{2} /$ pulse oximetry oxygen saturation ear sensor in newborn patients. Pediatrics 2005;115(1):e64-e68.

2. Senn O, Clarenbach CF, Kaplan V, Maggiorini M, Bloch KE. Monitoring carbon dioxide tension and arterial oxygen saturation by a single earlobe sensor in patients with critical illness or sleep apnea. Chest 2005;128(3):1291-1296.

3. Janssens JP, Howarth-Frey C, Chevrolet JC, Abajo B, Rochat T. Transcutaneous $\mathrm{PCO}_{2}$ to monitor noninvasive mechanical ventilation in adults: assessment of a new transcutaneous $\mathrm{PCO}_{2}$ device. Chest 1998;113(3):768-773.

4. Bolliger D, Steiner LA, Kasper J, Aziz OA, Filipovic M, Seeberger MD. The accuracy of non-invasive carbon dioxide monitoring: a clinical evaluation of two transcutaneous systems. Anaesthesia 2007; 62(4):394-399.

5. Delerme S, Montout V, Goulet H, Arhan A, Le Saché F, Devilliers $\mathrm{C}$, et al. Concordance between trancutaneous and arterial measurements of carbon dioxide in an ED. Am J Emerg Med 2012;30(9): 1872-1876.

6. Bendjelid K, Schütz N, Stotz M, Gerard I, Suter PM, Romand JA. Transcutaneous $\mathrm{PCO}_{2}$ monitoring in critically ill adults: clinical evaluation of a new sensor. Crit Care Med 2005;33(10):2203-2206.
7. Cox M, Kemp R, Anwar S, Athey V, Aung T, Moloney ED. Noninvasive monitoring of $\mathrm{CO}_{2}$ levels in patients using NIV for AECOPD. Thorax 2006;61(4):363-364.

8. Nicolini A, Ferrari MB. Evaluation of transcutaneous carbon dioxide monitor in patients with acute respiratory failure. Ann Thorac Med 2011;6(4):217-220.

9. Kelly AM, Klim S. Agreement between arterial and transcutaneous $\mathrm{PCO}_{2}$ in patients undergoing non invasive ventilation. Respir Med 2011;105(2):226-229.

10. Gancel PE, Roupie E, Guittet L, Laplume S, Terzi N. Accuracy of a transcutaneous carbon dioxide pressure monitoring device in emergency room patients with acute respiratory failure. Intensive Care Med 2011;37(2):348-351.

11. Perrin K, Wijesinghe M, Weatherall M, Beasley R. Assessing $\mathrm{PaCO}_{2}$ in acute respiratory disease: accuracy of a transcutaneous carbon dioxide device. Intern Med J 2011;41(8):630-633.

12. McVicar J, Eager R. Validation study of a trancutaneous carbon dioxide monitor in patients in the emergency department. Emerg Med J 2009;26(5):344-346.

13. Storre JH, Steurer B, Kabitz HJ, Dreher M, Windisch W. Transcutaneous $\mathrm{PCO}_{2}$ monitoring during initiation of noninvasive ventilation. Chest 2007;132(6):1810-1816.

14. Cuvelier A, Grigoriu B, Molano LC, Muir JF. Limitations of transcutaneous carbon dioxide measurements for assessing long-term mechanical ventilation. Chest 2005;127(5):1744-1748.

15. Janssens JP, Perrin E, Bennani I, de Muralt B, Titelion V, Picaud C. Is continuous transcutaneous monitoring of $\mathrm{PCO}_{2}\left(\mathrm{TcPCO}_{2}\right)$ over $8 \mathrm{~h}$ reliable in adults? Respir Med 2001;95(5):331-335.

16. Rodriguez P, Lellouche F, Aboab J, Buisson CB, Brochard L. Transcutaneous arterial carbon dioxide pressure monitoring in critically ill adult patients. Intensive Care Med 2006;32(2):309-312.

17. van Oppen JD, Daniel PS, Sovani MP. What is the potential role of transcutaneous carbon dioxide in guiding acute noninvasive ventilation?. Respir Care 2015;60(4):484-491.

18. Hanly PJ. Transcutaneous monitoring of carbon dioxide tension. In: Tobin M, editor. Principles and practice of intensive care monitoring. New York: McGraw-Hill; 1994:401-414.

19. Sørensen LC, Brage-Andersen L, Greisen G. Effects of the transcutaneous electrode temperature on the accuracy of transcutaneous carbon dioxide tension. Scand J Clin Lab Invest 2011;71(7):548-552.

20. Rithalia SV, Ng YY, Tinker J. Measurement of transcutaneous $\mathrm{PCO}_{2}$ in critically ill patients. Resuscitation 1982;10(1):13-18.

21. Maniscalco M, Zedda A, Faraone S, Carratù P, Sofia M. Evaluation of a trancutaneous carbon dioxide monitor in severe obesity. Intensive Care Med 2008;34(7):1340-1344.

22. O'Donoghue FJ, Catcheside PG, Ellis EE, Grunstein RR, Pierce RJ, Rowland LS, et al. Sleep hypoventilation in hypercapnic chronic obstructive pulmonary disease: prevalence and associated factors. Eur Respir J 2003;21(6):977-984.

23. Chhajed PN, Heuss LT, Tamm M. Cutaneous carbon dioxide monitoring in adults. Curr Opin Anaesthesiol 2004;17(6):521-525.

This article is approved for Continuing Respiratory Care Education credit. For information and to obtain your CRCE

(free to AARC members) visit www.rcjournal.com

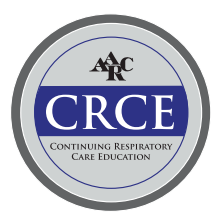

